\title{
Transatlantica
}

Revue d'études américaines. American Studies Journal

Line Breaks in America: the Odds and Ends of Poetry

\section{Noëlle Cuny and Xavier Kalck (eds.), Modernist Objects}

\section{Amy D. Wells}

\section{(2) OpenEdition}

1 Journals

\section{Electronic version}

URL: https://journals.openedition.org/transatlantica/16675

DOI: 10.4000/transatlantica. 16675

ISSN: $1765-2766$

\section{Publisher}

Association française d'Etudes Américaines (AFEA)

\section{Electronic reference}

Amy D. Wells, "Noëlle Cuny and Xavier Kalck (eds.), Modernist Objects", Transatlantica [Online], 1 | 2021, Online since 01 June 2021, connection on 04 February 2023. URL: http://journals.openedition.org/ transatlantica/16675 ; DOI: https://doi.org/10.4000/transatlantica.16675

This text was automatically generated on 4 February 2023.

\section{(c) (i) (2)}

Creative Commons - Attribution-NonCommercial-NoDerivatives 4.0 International - CC BY-NC-ND 4.0 https://creativecommons.org/licenses/by-nc-nd/4.0/ 


\title{
Noëlle Cuny and Xavier Kalck (eds.), Modernist Objects
}

\author{
Amy D. Wells
}

\section{REFERENCES}

Noëlle Cuny and Xavier Kalck (eds.), Modernist Objects. Clemson, SC: Clemson University Press, "Seminal Modernisms", 2020, 256 pages +8 pages of illustrations, ISBN (Hardback) 978-1-949979-50-3, ISBN (eBook) 978-1-949979-51-0, £90.

1 Modernist Objects is a thorough and diverse essay collection that will interest specialists and novices alike. Informed readers will appreciate the level of analysis each author brings to their selected corpus, and others will be set with a "to read" list. By approaching well-known modernist novels, poems, and art works from the angle of object aesthetics, the authors inspire us to reread and rediscover them, taking into account how objects are acting or interacting with themselves or people. The essays cover multiple genres (prose, poetry, and art) from a variety of theoretical approaches and lenses, ranging from psychoanalysis to Systems Theory, feminist approaches and intertextuality. Numerous essays addressing the visual arts are illustrated with black and white figures, and there are thirteen colored plates in the volume, making it a convenient reference for works by Klee, Louise Bourgeois, and the Baroness Elsa von Freytag-Loringhoven. Over half of the essays address or cite modernist women writers or artists, thus including a larger and more complete range of modernist expressions.

2 In their introduction, Noëlle Cuny and Xavier Kalck offer readers a panorama of object studies, tracing the interest of objects prior to and throughout the modernist period. Their thought process takes us through a series of questions regarding the material parameters of culture, if and how we should approach objects as "valid" objects of study, and how objects establish or efface borders between internal/external, otherness/self, and belonging/alienation. The editors remind us that "objects need us to say them into being" (7), and that our relationship to objects is co-dependent. The 
material turn, having passed from one discipline to another, has brought to the forefront the concept that objects both emerge and withdraw. The ensemble of these questions can be found at the very center of modernism. In this way, the essay collection privileges an aesthetics approach to modernist objects. The essays are divided into three thematic sections of four chapters each, taking readers on a modernist foray throughout complimentary methods to object studies. Each part is based on a process at the core of modernist object experiments: objecting to realism, fashioning the human, and performing the ornamental.

The first part, "Objecting to Realism," gives readers the chance to see modernists' negative reactions to, objections to, and even fear of objects, and how the distress caused by them can lead to a revelation. In "Objectionable Objects", Douglas Mao questions if his initial conclusions from Solid objects (1998) regarding modernist affection for objects holds up even when characters, authors, and artists confront upsetting objects. Through his discussion of Wyndham Lewis's Snoot Baronet (1932), La nausée (1938) by Sartre, and Michael Fried's "Art and Objecthood" (1967), Mao contrasts objects with works of art, distinguishing what makes the latter special, or aristocratic. In challenging the meaning and value of objects in comparison to those of works of art, the author concludes that it is the relationships between objects themselves that can create meaning and significance. Objects and humans are connected through a network of relationships. Beckett's relationship to his objects and the literary traditions of Balzac and Proust are the topic of study for Martin Schauss in the second chapter as he argues that Beckett's post-war prose (1946-1951) and its material emptiness is an intentional strategy. Characters from this "siege in the room" period turn to everyday material things as a way to seek comfort. Schauss first addresses the furniture of Balzac's bourgeois room before turning his attention to the "Beckettian" objects of the hat and greatcoat that have, for the author, become "stale" after having trickled down through Proustian intertextuality. Beckett's hat remains symbolic, but mainly in relation to the repetition of things in a text. For Schauss, the presence of lost objects renders them ghostly, underscoring the indetermination characterizing Beckettt's post-war works.

4 As readers continue through the first part of the essay collection, they encounter other difficult or upsetting objects. Pavlina Radia offers us a comprehensive reading of Djuna Barnes, covering the range of her early writings including poetry, short stories, and theater; the (in)famous Nightwood; but also The Antiphon, demonstrating the constant presence of modernist objects in the Barnesian corpus. Radia approaches Barnes through Sara Ahmed's The Cultural Politics of Emotion (2004), arriving at the lens of affective mobilities. She thus demonstrates how Barnes uses objects as markers of the impersonal, "but also as affective spaces where socio-political, ethical, gender, and racial conflicts are mobilized" (64). Radia suggests we shift our focus from reading Barnes's work biographically, solely steeped with trauma and shame, to rather view "Barnes's texts as affectionately embracing the vibrant materiality of objects as a sociocultural commentary on American modernist aesthetics and American modernity" (65). In three examples from the early works, characters wind up being compared to objects and existing through them: in "Suicide," Corps B is, "like a beer gone flat"; the eponymous character becomes aligned with the banjo she plays in "Paprika Johnson"; and Mme Boliver is compared to "some rare wood" in "Indian Summer." 
5 Radia opposes the fiction and poetry that rely on natural objects to the plays that conjure up mass-produced industrial objects. In the play "Five Thousand Miles: A Moral Homily Inspired by All the Current Talk about the Wild Free Life in the South Seas" (1923), an eggbeater "crashes" the isle idyllic, and Radia provides cultural proof of the eggbeater's place in domestic spaces and imaginations as sexualized and gendered. As the essay turns to Nightwood, the setting of Robin and Nora's rue de Cherche-Midi apartment could not be more propitious for a discussion of collecting objects and how the characters can "love-hate" them together. The novel concludes on the "raw essence of things," a concept that culminates in the later play, The Antiphon, where the dilapidated setting and use of a miniature puppet theater reinforce the motherdaughter antiphony. For its analysis of objects across the corpus, this article is an exciting contribution to Barnes scholarship.

6 In "Tradition and the Test-Tube Baby," Rachel Bowlby takes us through the genesis of extra-uterine conception resulting in a 1978 live birth. She retraces the agricultural origins of artificial insemination and how the transfer of this technology to treat human infertility was then known under the term, "test tube baby." The scientific approach is crossed with literary citations to demonstrate just what is gained or lost through the test tube. Huxley's Brave New Word (1932) makes clear the separation between reproduction and sexuality, giving way to contraception and its power of choice. From Freudian psychoanalysis, the article goes forward with the image of "testtube minds," or mixes of fluctuating mental processes producing what is commonly called "chemistry" between people. Eliot's "Tradition and the Individual Talent" (1919) calls forward the "receptacle" of the poet's mind where a chemical reaction takes place. In a final, pertinent example, Bowlby revisits the Chloe and Olivia scene from "A Room of One's Own" (1929) through the perspective of the test-tube. As the two women share a laboratory, this space can be perceived as one of female emancipation and progressive medical science. Readers learn through this article that the test-tube has had long-lasting impact: ultrasound scanning, now a standard procedure, was originally conceived of for IVF monitoring.

7 After the study of these "objectionable objects," the second part of the volume is dedicated to the process of "fashioning the human," and the articles often address the fluid boundaries between objects and humans. Sanja Bahun takes us into the art worlds of Paul Klee, Varvara Stepanova and Lyubov Popova, where we can see common home objects encrusted in works of art, and the process of making art molded and embellished by the daily. More specifically, Bahun focuses on Klee's 1921 paintings on cheesecloth and the 1924 textile designs from the Russian artists. Bahun launches the discussion with positive (shelter, orient comfort, and nurture) and negative (stifling, discomforting, and dangerous) concepts of home, and the relationship between home and everyday objects. This relationship may be metonymic or a metonymic chain, and in the examples given, all artists worked from home, a space that was shared between family and professional activities. Household cloth in the form of cotton textiles such as muslin, burlap, and gauze, became a source of experiment for Klee, and Bahun suggests the repeated recourse to this material reveals a strategy of bringing the semantic, emotional, and expressive particulars of home into the painting. Klee's Revolving House is painted on cotton cheesecloth that is sometimes visible and sometimes not. The analysis demonstrates how the cotton textiles contribute meaning three-fold: the continuity of a material object and its concrete use in a household setting; the image of 
house/houses; and finally, representing the scope of home. In this way, the cloth determines the "texture of expression-[...] what happens in the painting" (102).

Turning attention to artists Stepanova and Popova, members of the Productionist movement, readers understand how the object can become a co-worker or even a comrade, an active participant in the process of creation. The two women were hired at the First State Textile Printing Factory to oversee how the process of producing everyday objects could be done in a more creative and stimulating setting. A cycle of home-factory-home emerged when Stepanova took a sample of her work back home, emphasizing the relationship of objects to their context. In a phrase that could just as well be about the current COVID situation as the working and creative conditions of the artists discussed, Bahun states: "As boundaries between home and non-home become permeable and the uses of home expand, so the material object ceases to be whole in terms of both its 'completeness' and its unique use-trajectory, and opens up to the nondeterminate and the unforeseeable" (109). Ultimately, this textile sample is a true modernist object as it is in a constant state of process (deterioration).

This focus on process continues in Chapter 6 as Louise Kane makes it possible for us to understand the feeling and experience of little magazine modernity. She does so through an analogy with computer science and within the frame of Systems Theory, bringing forward the concept of reflexivity and its place in Modernism and in relationship to objects. After positing that Modernism has both gone bigger and smaller, Kane questions the digitalization of little magazines, and how that particular practice, although increasing access, might hinder the spirit of a mixed-media reflective experience. She puts forward that when we concentrate on the magazine's immutable status as "object" instead of solely addressing the mutable status of "modernist", we can reconsider the magazine's materials and multiple modernisms. Specifically, reading magazines as a metaobject makes it possible to take into account how they are constantly in flux, in the process of rewriting themselves, entering into a system composed of editors, contributors, publishers, printers, and distributors. This exciting discussion moves through examples from Rhythm (1911-1913), Shirakaba (1910-1923), The Crisis (1910-1923), and The Little Review (1914-1929), establishing modernism as a "live, continual act" (126). The analysis opens up to a post-colonial perspective by including details about the magazine Kyk-Over-Al (1945-). Kane concludes that the magazine, as metaobject, receives its self-consciousness from its readers.

10 Jennifer Kilgore-Caradec opens her essay with a brief history of harps and lyres and their presence within global bardic traditions, from B.C.E. through the modernist period, and across literary traditions, ranging from Wales to South Africa. As a result of these shared traditions, the terms scop, bard, fili, skald, and griot are present at the early twentieth century. Kilgore-Caradec retraces the poetic presence of harps and lyres in a series of over twenty citations. In her discussion of "Harps of Modernist Men," she takes us through poetic extracts from Yeats, James D. Corrothers, Po Chu-I published by Ezra Pound in The Little Review, brothers Sacheverell and Osbert Sitwell, Eliot, and Aldous Huxley to conclude with Jean Cocteau's cinematographic representations of harps and lyres. As these first examples reinforce the presence of harps and lyres, Kilgore-Caradec moves to the discussion of the use of these objects amongst female writers and poets in "Feminist Harps." Marianne Moore's poem, "That Harp You Play so Well" (1915) leaves the impression that "woman's place as harpist-poet is still 
problematic" (141). Edith Sitwell, publishing in Wheels as her brother, also relies on lyre imagery. Edna St. Vincent Millay's "The Ballad of the Harp-Weaver" (1922) immortalized by Johnny Cash on YouTube, is associated with the Christmas holiday. H.D.'s "The Walls Do Not Fall" (1942) argues that poetry with the lute predates the sword, moving us towards Kilgore-Caradec's message in the last section, "Harps of War." Through her discussion of citations from Wilfred Owens, Auden, and MacNeice, she argues that poetry is a counterpart to war-poetry is an ally to peace.

11 The section wraps up in Chapter 8 with Lynn M. Somers's "Louise Bourgeois's Melancholy Objects to be Used." In this article, Somers shows us how Bourgeois's Personages sculptures may be interpreted as material objects, symbolic objects, and transitional objects to be used. The lesson here is that the same art objects, the various wooden monolith sculptures dating from the post World War II period, may be perceived in these three different ways as "complicated fictions rather than truths" (151). While reminding us of the previously identified themes in Bourgeois's work such as motherhood, domesticity, and autobiography, Somers helps us to envision how the Personages units were intended to actively function together as a group in an exhibit space, to be moved around, and in some cases, to be repositioned according to their moveable parts (as for Sleeping Figure). Somers calls upon the psychological work of D.W. Winnicott and how it shaped transitional phenomena in the postwar context to emphasize how the Personages can "behold and use two or more opposite or contradictory ideas or images at the same time: vertical/horizontal, inside/outside, abstract/figurative, emotional/rational, stable/unstable, unity/dissonance, and so on" (150). Bourgeois herself insists on the dynamic nature of the Personages by giving specific instructions for their "possibility for use" and how they should perform, as they are not mere sculptures but "functional avatars" for people. Somers's take on these objects invites us to view them as "good objects."

12 Moving to the final part of the essay collection, readers confront the concept of "performing the ornamental," while there will also be the question of performing the oriental in chapter 10. But first, the section opens up with Yasna Bozhkova's text, “Limbswish: Baroness Elsa's 'Ready-to-Wear' Poem-Objects." In her analysis, Bozhkova reminds us just how innovative, cutting edge, and titillating Baroness Elsa was. The Baroness's creations were intermedial and hybrid, breaking down barriers regarding art and poetry genres and forms. Her readymades, ready-to-wear creations, and object poems and poem-objects came together under a unique umbrella of poetics of objects. Bozhkova recalls the chronology of the use of mass-produced, found items: the Baroness used found objects starting from 1913, two years prior to Duchamp's arrival in New York. She also invented a new genre now known as "the corporeal readymade," in which she used her own body to display objects, creating a "living assemblage, which blurred the boundaries between the art sphere and everyday life, artists and artwork" (173). The two photographs included in the essay help readers imagine what it might have been like to encounter the Baroness on the streets of New York. Furthermore, the analysis includes an extract from "Subjoyride" (1920-1922), a poem that captures consumer objects within its staccato lines, producing a type of Dada "subvertising." Long before the mainstreaming of up-cycling trends, the Baroness rescued objects of rejected daily consumerism and endowed them with new artistic meanings.

13 In the next chapter, Maurizia Boscagli undertakes both the history of design tensions between Eileen Gray and Le Corbusier but also two different approaches to orientalism. 
Readers unfamiliar with Gray's history will be fascinated to learn how the lacquer designer evolved to become an architect, and how her own need for a nonheteronormative space influenced her designs. Boscagli argues that Gray's work is alter-modernism, or "an aesthetic in open contrast with the technological, productivist, and fast-paced view of modernity that lies at the core [...] of the dominant narrative of modernism" (190). Furthermore, she relies on an ornamental Orientalism as is expressed through her lacquer work and architecture that privileges comfort and horizontality. For Boscagli, Gray's orientalism is in stark contrast to that of Le Corbusier's, in which he obsessively fetishizes colonial women's bodies, and ultimately, Gray "dazzles and blinds the male gaze" in her works. To demonstrate this argument, Boscagli unpacks the creation of La Pirogue (1919/1920) and the design and construction of E. 1027, in Roquebrune (1926-1929). We understand that Gray designs for her own needs of intimate space, emphasizing disorientation and privacy, comfort and sensuality. The article recognizes the different points of conflict between Gray and Le Corbusier, including Le Corbusier's murals painted on the white walls of E. 1027 once Gray no longer lived there. For their bold colors, sexualized scenes, and repeated nude female bodies, these murals have been considered a violation or even rape of Gray's house. Boscagli suggests Le Corbusier was obsessed with Gray and never ceased trying to possess her symbolically through his murals, his choice of residence, or even the location of his death. The article concludes with the invitation to pursue the study of Eileen Gray's alter-modernism, and readers are motivated to do so.

From the larger creation of a house or furniture piece, readers switch scale to a smaller object, the brooch, in chapter 11. Nonia Williams draws our attention to what happens to symbolism when "common things" are broken, lost, or forgotten in the works of Katherine Mansfield, Virginia Woolf, and Gertrude Stein. Williams also seeks to question the "feminine" nature of precise details and their significance through Naomi Schor's aesthetics of absent details. In "Pictures" (1919), Mansfield employs two different brooches on the same page: one is a bunch of artificial violets at the woman's bosom, and the other is a brooch with "Dieppe" written on it. As the first one is artificial and the second one is the topic of repetition within the text underscoring the young woman's attractiveness, the brooches function to establish the status of each woman as real or fake, desirable or undesirable. Next, Williams pairs Mansfield's "At the Bay" (1921) with Woolf's To the Lighthouse (1927), reminding readers of a potential influence or intertextuality between the two through the shared lost object of a brooch. Woolf's lost brooch represents a weeping willow set in pearls, a jewel inherited by Minta Doyle from her grandmother and regretfully lost at the beach. Williams points out that the brooch is described in detail only after its loss, and the symbolism of mourning and loss of the object's design itself foreshadows multiple layers of loss within the novel.

Although there is no proof that it is Minta's lost brooch from Woolf's work, a sign does show up in Mansfield's "At the Bay" in Mrs Stubb's shop, declaring: "LOST! HANSOME GOLE BROOCH." Given the unlikelihood of actually finding the brooch now, it is the sign itself that has become the object. Furthermore, the language of the sign indicates the characters losing brooches are not of the same social class. These examples work to prove that objects in absentia actually work to recall their "thingness" and symbolic relevance to the text. As Williams turns her attention to Gertrude Stein's The Autobiography of Alice B. Toklas (1933), she does not address Stein's coral brooch that figures prominently in the Picasso portrait (1906) and that is equally cited by Alice in 
The Autobiography as being one of the very first elements that struck her about Gertrude. Rather, the passage cited focuses on Stein's admiration for "breakable, cheap objects and valuable objects" (220). These "throwaway" objects are "modern" through their mass-production, and it is suggested that Stein is enthusiastic to replace them when they break because for her, the fragility and memory of an object bring more pleasure than a repaired one. Williams concludes that readers must pay attention to the "absent, lost, broken, forgotten and cancelled details" in works by women writers (223).

16 The volume concludes with an essay about Jean Rhys's Good Morning, Midnight (1939). Justine Baillie reads Rhys's expatriate text through the lens of Walter Benjamin's The Arcades Project (1927-1940), suggesting both writers "share a Baudelaireian modernism as critique of modernity" (227). Putting forward Rhys's perspective of a "displaced and dispossessed Caribbean exile," Sasha's story is far from the fun and folly of other Left Bank texts. On the contrary, the narrator, whose national identity is unknown, is left "adrift in a city of objects" (225). Hearing Martinique music and acquiring the portrait of a banjo player recall her Creole past, and these memories seem to play in a non-stop loop. What Sasha needs is to escape death by making herself invisible, less noticeable, and to do so, she buys a new hat, a new coat, gets a new haircut, or a new black dress. But the consumption of these objects fails her, because she cannot blend into her surroundings since she continues to wear her fur coat. Despite her derelict state, this coat makes her the target for potential exploitation because it suggests she has money. Baillie tells us, "Rhys's modernism has a pessimistic, indeed nihilistic, inflection as, for Sasha Jensen in Good Morning, Midnight, there is no revolutionary awakening or liberating epiphany" (232). Despite acquiring additional ornaments, Sasha remains lost in a city on the brink of war.

Through this roll call of natural, mass-produced, and artistic objects, ranging from puppets, automats, tree roots, furniture, eggbeater, flat beer, banjo, rare wood, test tubes, ultrasound scanning, pregnancy tests, "comrade" cotton, little magazines, harps and lyres, wooden sculptures, industrial and domestic trash, walls and murals, brooches, a black dress, and hat, each essay has brought us a new perspective on its corpus. We understand better through this objects-aesthetic approach how objects are functioning within literature or art, and in some cases, the particular connection of the objects to the writer or artist. As we read these essays from the blurred borders between objects and people and their relationships, we continue to perpetuate modernist objects.

\section{AUTHORS}

\section{AMY D. WELLS}

Université de Caen Normandie 